\title{
Understanding Role of Mobile Apps in Smart City Services
}

\author{
Yatin Jog, Ramamurthy Venkatesh, Anubha Pandit, Rahul Singh Bhadauria and \\ Padmavati \\ Symbiosis Institute of Telecom Management \\ Symbiosis International University, Pune, India \\ yjog@sitm.ac.in,venkatesh@sitm.ac.in,anubha.pandit@sitm.ac.in, \\ rahul.bhadauria@sitm.ac.in,padmavati.ch@sitm.ac.in
}

\begin{abstract}
With the advent of new generation technologies and information driven "intelligent solutions", Smart City Projects are underway in many parts of the globe. Country level guidelines and implementation approaches may differ but key components of smart city solutions are same. In particular, urban mobility solutions and smart infrastructure services such as smart waste management are gaining momentum with the involvement of local municipal bodies and government institutions. This paper aims at reviewing and summarizing some of the developments in Urban mobility, smart waste management and smart retail solutions that are being implemented in various cities. Use of mobile apps, congestion pricing, interconnected mass transit systems are fostering growth of urban mobility adoption rapidly. In similar lines Smart Waste Management solutions are also moving beyond simple sensor based waste collection binds to integrated waste recovery and disposal systems driven by ICT applications, through management of data on all levels by all stakeholders. Lastly, success in the retail industry is all about timing, precision. innovative software applications, wireless devices ePOS Stations are giving rise to growing Smart Retail solutions across different value chain. Given the above premise, an attempt is made to envisage three key components of smart city solutions and the growing trends in the coming years.
\end{abstract}

Keywords: Urban mobility, Smart Waste management, Smart Retail, Smart communities

\section{Introduction}

Smart Cities are indicators of developed economies. Once the citizens upgrade and update themselves, a developing country can become a developed one. Smart City is in full swing in India and around 20 cities have been selected by the government in the current stage of implementation. The mission mainly concentrates on innovation and technology to drive the growth of the cities and provide a better place for the citizens to live in.

Within the concept of Smart Cities, citizens' involvement is highly influential. This involvement can be entertained through mobile applications on their smart phones as smart phone has become the necessity of every urban citizen. To convert cities into smart, the problems of the citizens must be addressed in a smart way. As per recent research reports, global smart city market including smart mobility, smart healthcare and smart infrastructure is illustrated as below. 


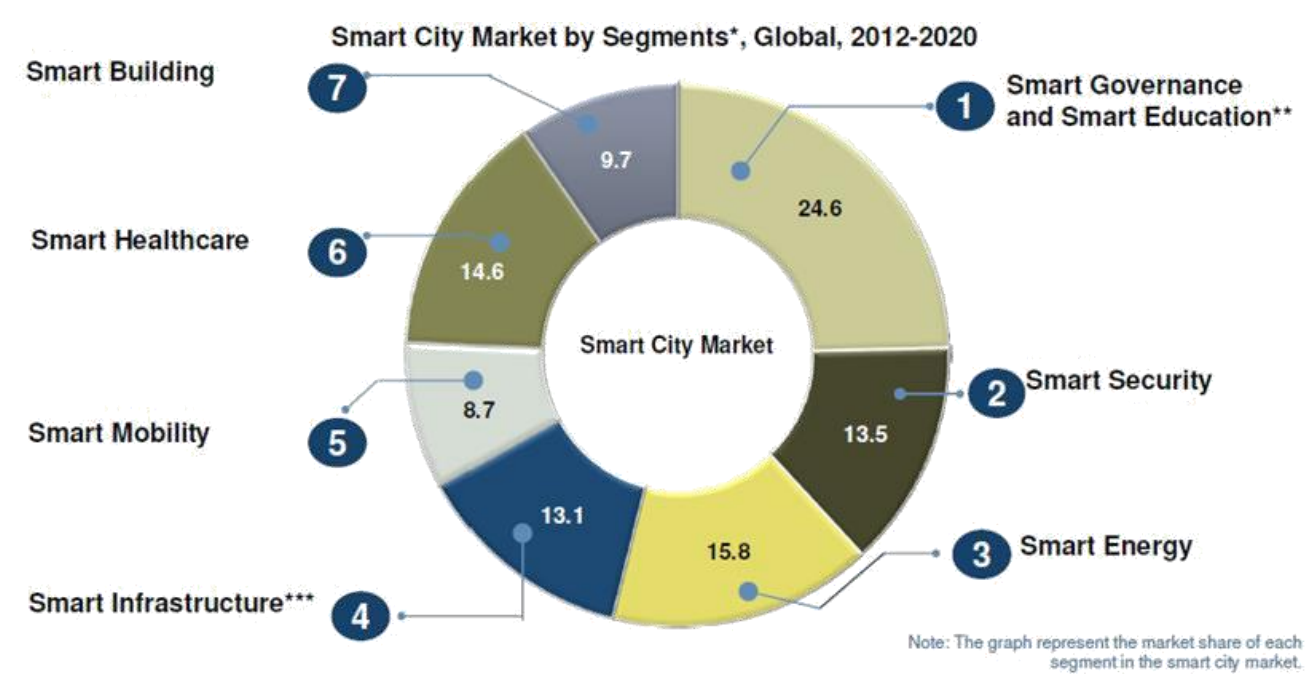

Figure 1. Smart City Market by Segments

In other words, smart city plans worldwide include components of smart urban mobility, smart retail, smart waste management, smart health, smart agriculture, smart grid, etc. For this research, urban mobility, smart waste management and smart retail are taken into consideration.

Urbanization is growing, placing intense pressures on city infrastructure and its resources. Urban Mobility is going to be one of the toughest challenges for cities around the world.[1] Mobility infrastructure has been ranked one on priority for those cities those are seeking to attract investors, and as such many growing cities have put this at top in agenda. It is found that affordable and efficient means of mobility for public-at-large can be crucial enablers of economic growth[2].Like any other country, India is also facing various mobility challenges such as significant rise in urbanization, road congestion, fuel prices, pollution, road accidents and health issues. Unless these problems are addressed in right perspective, this poor and painful mobility can affect adversely the economic growth and cause the quality of life to deteriorate. These problems can be resolved by multiple options. For instance, Real Time Journey Information, Smart Payment, Sharing resources (car and Bike pulling), Smart Parking, Balance of Demand and Supply etc. are going to be preferred options for solving urban mobility issues.

With the increase in population and change in the lifestyle patterns, humongous amounts of waste are generated in the country. So the need of the hour is to optimize the management of this service to reduce infrastructure, operating and maintenance costs, as well as reduce contamination directly associated with waste collection. This can be done with the help of Smart Waste Management by applying technology to the current operating system.

The internet of things (IoT) is driving innovation and new possibilities by means of bringing every object and client into the virtual realm. Retail has direct touch with potential purchasers that completely embrace generation and innovation. [3] Stores want to stay abreast with the modern day technology to earn the loyalty of the subsequent-era customer and capitalize on emerging business possibilities. The patron demands for comfort, product availability, and each personalised and contextualized interactions, as a result the shops are driven to adopt the changing IoT technology inside the coming years. 


\section{Urban Mobility}

The real-time journey apps help you plan your journey before leaving and gives you clear idea of any congestion on any path. Citymapper is an integrated real time journey planning app which has successfully launched in London and New York [1]. The online and mobile service incorporates all possible routes across the city using all public transit modes, bike share options, pedestrian routes and real time service updates, together with pricing information of each transport mode.

For future scenario it is said that urban cars will need to be customizable, autonomous, green and shared with others. This will catalyse the trend which is seen toward car sharing versus ownership and expand shared services (whether car or bike) to a new level of convenience and flexibility" [4]. Car sharing apps help users find inexpensive car rental and borrowing opportunities offered by other app users in their local community. For instance, BlaBlaCar is a trusted community marketplace which connects drivers with riders. Driver with empty seats meets with co-travellers looking for a ride. These apps are making travel social, more efficient and money-saving for millions of members.

Smart Parking App puts the driver in control of their day. It removes the stress of driving around and finding a space which for parking [1]. This app helps finding the best space availability for each driver and directing them to it. Driver uses smart parking app to check parking choices and availability at their desired place before setting out. These Apps gives the driver full details of parking option available including prices, out-of- hour times and any restrictions.

\subsection{Qualitative Analysis of Mobile Applications in Urban Mobility}

\begin{tabular}{|c|c|c|c|}
\hline Name of the app & REGION & Functioning of the app & Comments/ Recommendations \\
\hline $\begin{array}{c}\text { Together We } \\
\text { Go(ToGo) }\end{array}$ & Mumbai, India & $\begin{array}{l}\text { This app is trying to } \\
\text { build trusted } \\
\text { communities on all } \\
\text { routes of the city. So } \\
\text { that, any member can } \\
\text { carpool to office daily } \\
\text { with other likeminded } \\
\text { people. It will add you } \\
\text { to Chat groups like } \\
\text { Whatsapp for } \\
\text { carpooling based on } \\
\text { home-office route. By } \\
\text { using this app car } \\
\text { owners can share their } \\
\text { fuel cost with co- } \\
\text { travellers, while co- } \\
\text { travellers may find a } \\
\text { daily commute partner } \\
\text { at nominal cost. }\end{array}$ & $\begin{array}{l}\text { People have used this app in } \\
\text { Mumbai. They are finding it } \\
\text { best and very innovative } \\
\text { carpooling app in India. By } \\
\text { using this app people are able } \\
\text { to find rides on their office } \\
\text { route and saving big bucks. } \\
\text { People like its group and chat } \\
\text { function. They got option for } \\
\text { going to and from home to } \\
\text { office. User friendly GUI and } \\
\text { easy to understand app and } \\
\text { traffic updates are value } \\
\text { addition. }\end{array}$ \\
\hline Bla-Bla Car & 22 countries & $\begin{array}{l}\text { BlaBlaCar is a world's } \\
\text { largest trusted } \\
\text { community who shares } \\
\text { long distance rides. It } \\
\text { has more than } 25 \\
\text { million users in a total } \\
\text { of } 22 \text { countries. It is a } \\
\text { community that } \\
\text { connects drivers who }\end{array}$ & $\begin{array}{l}\text { In a flow of creating smart } \\
\text { cities, safety is also one aspect } \\
\text { to look upon. Women can } \\
\text { travel with female members } \\
\text { only to allow members to plan } \\
\text { a ride share where the car } \\
\text { owner and all co-travellers are } \\
\text { women. }\end{array}$ \\
\hline
\end{tabular}




\begin{tabular}{|c|c|c|c|}
\hline & & $\begin{array}{l}\text { has empty seats to the } \\
\text { co-drivers who are } \\
\text { looking for a ride. }\end{array}$ & \\
\hline Lyft & San Francisco, US & $\begin{array}{l}\text { Lyft is a privately held } \\
\text { American Transport } \\
\text { Network Company } \\
\text { based in San } \\
\text { Francisco. The } \\
\text { company's mobile app } \\
\text { facilitates people with } \\
\text { peer to peer ride } \\
\text { sharing. It connects } \\
\text { drivers who have cars } \\
\text { to passengers who } \\
\text { need a ride. Except its } \\
\text { availability in 200 U.S. } \\
\text { cities, this is available } \\
\text { in Indonesia, Malaysia, } \\
\text { Singapore, Thailand, } \\
\text { Philippines and } \\
\text { Vietnam. }\end{array}$ & $\begin{array}{l}\text { People in U.S. find it very } \\
\text { useful. Users of Lyft app in } \\
\text { U.S. are in large numbers, so } \\
\text { these cars are always available. } \\
\text { The cash less trip is very much } \\
\text { safe and due to trusted profiles } \\
\text { and background of car owners, } \\
\text { people find it safe and secure } \\
\text { service. People are very much } \\
\text { happy with this app and that's } \\
\text { why they gave } 4.3 / 5 \text { rating to } \\
\text { this app. }\end{array}$ \\
\hline PParkE & India & $\begin{array}{l}\text { This app will } \\
\text { troubleshoot all the } \\
\text { parking problems in } \\
\text { the city. You may } \\
\text { know the parking } \\
\text { availability in advance; } \\
\text { you may come to know } \\
\text { the rates of the parking } \\
\text { on hourly basis, } \\
\text { booking of your } \\
\text { parking space online } \\
\text { and you can pay from } \\
\text { wallet. If you have } \\
\text { parking space } \\
\text { available, you can } \\
\text { become partner with } \\
\text { them and generate } \\
\text { revenue. }\end{array}$ & $\begin{array}{l}\text { People liked this smart parking } \\
\text { initiative by PParkE. But they } \\
\text { want the app team to include } \\
\text { more places for parking } \\
\text { because whichever are shown } \\
\text { is not sufficient sometimes. } \\
\text { And sometimes people had } \\
\text { issue of wrong listing of } \\
\text { parking rates online. If some of } \\
\text { these areas will be improved, } \\
\text { then this initiative will be a } \\
\text { huge success. }\end{array}$ \\
\hline ParkPnP & Dublin, Ireland & $\begin{array}{l}\text { ParkPnP allows you to } \\
\text { discover cheaper and } \\
\text { more affordable } \\
\text { parking in desired } \\
\text { locations at the click of } \\
\text { a button. ParkPnP } \\
\text { works as a marketplace } \\
\text { that facilitates people } \\
\text { to list, advertise and } \\
\text { then generate income } \\
\text { from their unused or } \\
\text { underutilized parking } \\
\text { spaces. Your space } \\
\text { will be advertised to }\end{array}$ & $\begin{array}{l}\text { To solve parking problem in } \\
\text { smart city, the initiative of pre } \\
\text { booking of parking place was a } \\
\text { must thing to do. By this app, } \\
\text { if you have unutilized parking } \\
\text { space, you can generate some } \\
\text { revenue out of it and if you are } \\
\text { finding some space for } \\
\text { parking, you can book that } \\
\text { place in advance and you can } \\
\text { enjoy shopping or your } \\
\text { meeting tension free. }\end{array}$ \\
\hline
\end{tabular}




\begin{tabular}{|c|c|c|c|}
\hline & & $\begin{array}{l}\text { potential parkers from } \\
\text { across the country. }\end{array}$ & \\
\hline SFPark & San Francisco, US & $\begin{array}{l}\text { SFpark is San } \\
\text { Francisco's system for } \\
\text { managing the } \\
\text { availability of on-street } \\
\text { parking. Reducing } \\
\text { traffic by helping } \\
\text { drivers find parking } \\
\text { benefits everyone. } \\
\text { More parking } \\
\text { availability leads to } \\
\text { streets less congested } \\
\text { and safer. Meters that } \\
\text { accept credit and debit } \\
\text { cards reduce } \\
\text { frustration and parking } \\
\text { citations. }\end{array}$ & $\begin{array}{l}\text { SFpark makes finding and } \\
\text { paying for parking faster and } \\
\text { easier. Demand-responsive } \\
\text { pricing information, via text, } \\
\text { and through smartphone apps } \\
\text { helps drivers find a space. } \\
\text { With parking faster to find and } \\
\text { pay for, it's going to be easier } \\
\text { to enjoy the City's commercial } \\
\text { areas. }\end{array}$ \\
\hline CityMapper & $\begin{array}{l}\text { U.S., Canada, } \\
\text { Europe, Asia }\end{array}$ & $\begin{array}{l}\text { Citymapper is the } \\
\text { award-winning transit } \\
\text { app making complex } \\
\text { cities easy to use. It } \\
\text { provides A to B trip } \\
\text { planning with ETA } \\
\text { (Estimated Time of } \\
\text { Arrival) including all } \\
\text { modes (subway, bus, } \\
\text { rail, bike/car sharing), } \\
\text { Real-time departures. } \\
\text { Transit maps, Bike } \\
\text { routing and live bike } \\
\text { share information, } \\
\text { constant updates, Line } \\
\text { status and real-time } \\
\text { disruption alerts these } \\
\text { are the features of this } \\
\text { app. }\end{array}$ & $\begin{array}{l}\text { It's a must have app for many } \\
\text { users. People are calling it best } \\
\text { transport app ever. The best } \\
\text { feature people liked is its alarm } \\
\text { ringing system, whenever your } \\
\text { station arrives where you need } \\
\text { to get down. People found } \\
\text { many areas for the scope of } \\
\text { improvement like making it } \\
\text { more users friendly, more } \\
\text { interactive etc. And app should } \\
\text { be available in many other } \\
\text { regions of the world. }\end{array}$ \\
\hline Moovit & $\begin{array}{l}800 \text { cities across } \\
60 \text { countries }\end{array}$ & $\begin{array}{l}\text { Moovit offers real-time } \\
\text { public transit } \\
\text { information and GPS } \\
\text { navigation across all } \\
\text { the possible transit } \\
\text { modes. This app } \\
\text { differs from traditional } \\
\text { public transit apps as it } \\
\text { is community-driven } \\
\text { and integrates official } \\
\text { public transit data with } \\
\text { real-time data collected } \\
\text { from users via } \\
\text { crowdsourcing. It then } \\
\text { integrates this crowd }\end{array}$ & $\begin{array}{l}\text { The ratings submitted by } 4 \\
\text { lakhs people. And they gave } \\
\text { rating of } 4.3 \text { out of } 5 \text { for this } \\
\text { app. The number shows the } \\
\text { trust of people for this app. } \\
\text { They found it very accurate } \\
\text { and user friendly. Its UI is very } \\
\text { simple, easy and } \\
\text { understandable that a person of } \\
\text { any age group can operate it. } \\
\text { Most of the people are fully } \\
\text { dependent on this app. This } \\
\text { app is increasing its reach to } \\
\text { more number of cities across } \\
\text { the world. }\end{array}$ \\
\hline
\end{tabular}




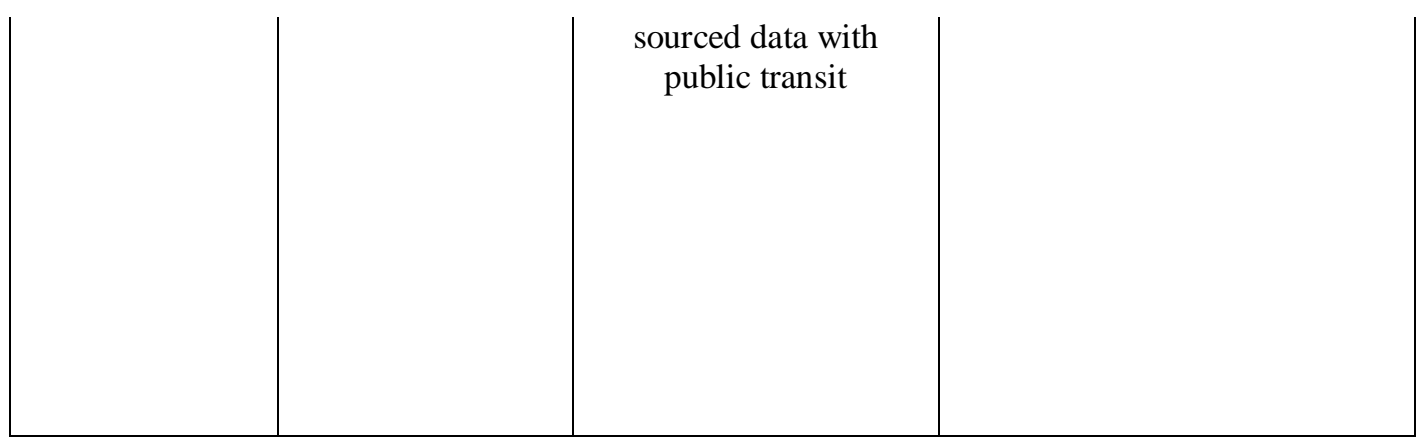

Industry associations, city authorities and other stakeholders worldwide have now formed UITP an international association for urban mobility. Various initiatives of UITP are now underway in different parts of the world. Recently, UMii, the first Urban Mobility Innovation Index, was officially launched on 28th August 2016 by Sheikh Hamdan Bin Mohammed Bin Rashed Al Maktoum, the crown prince of Dubai.The project, initiated and sponsored by the Roads \& Transport Authority of Dubai (RTA), aims to provide a guide for cities around the world to foster innovation in their urban mobility services and systems. UMii is being implemented by UITP with the support of Future Cities Catapult.[9]

UITP (www.uitp.or) represents 1,400 member companies giving access to over 18,000 contacts from the fields of urban, local, regional and national mobility from more than 96 countries on all continents.[10]

\section{Smart Waste Management}

Fundamentals of waste management: Rethink, Reduce, Recover, Reuse and Recycle. With the progress of the nation towards smart cities, the above fundamentals have to be taken care of in a smart way, which calls for Smart Waste Management.

INDIAN SCENARIO

With the changes in lifestyle patterns, urbanization, increase in disposable incomes of the citizens have paved way for consumerism, that indirectly leads to increase in waste generation in India. India is one of the largest consumers of electronics and if continued, would be the fifth one by 2025 . This would direct towards generation of e-waste which is highly toxic and non-decomposable. [5]

There is a lot of inefficiency in the present waste collection:

- Consumes time - without being aware of whether containers are full or not, trucks go and empty them.

- Soaring costs.

- Congestion and lot of traffic flow.

- Needless fuel consumption. [6]

\section{GLOBAL SCENARIO}

Amongst the regions as in APAC, MEA, Europe and Americas, APAC is supposed to generate the most industrial waste in the world, followed by the Americas, Europe and lastly MEA. The Americas have strong interest in efficient collection, sorting and recycling technologies. It is the global leader in industrial waste recycling rates, with high production levels in a wide range of waste-generating industries. [7]

Contribution of Mobile Applications towards SWM

As mobile services are becoming cheaper and more accessible in recent years, smart waste management solutions can be provided by applying technology to the existing operation system to enable communications both ways, amid the operators and the infrastructure structured in the city. [6] There is also a different aspect that should be taken into account when considering the relation that mobile phones have with recycling and waste management. The large amount of mobile phones and tablets that are entering 
the market, result in greater e-waste quantities of special materials that need to be handled after use. The complex construction of such devices makes difficult their dismantling and subsequently their disposal too. Mobile devices have valuable metals and parts that need special care. The more technologically advanced a device is the more complex its waste disposal is.

\subsection{Qualitative Analysis of Mobile Applications in SWM}

\begin{tabular}{|c|c|c|c|}
\hline Name of the app & REGION & Functioning of the app & $\begin{array}{c}\text { Comments/ } \\
\text { Recommendations }\end{array}$ \\
\hline $\begin{array}{l}\text { I clean India } \\
\text { mission }\end{array}$ & India & $\begin{array}{l}\text { Allows citizens to post } \\
\text { photos of unclean areas } \\
\text { in their region and } \\
\text { mark it on app, and } \\
\text { organize a cleanliness } \\
\text { drive for same. The } \\
\text { app connects to } \\
\text { Facebook and Twitter } \\
\text { accounts of the user } \\
\text { and allows the user to } \\
\text { post photos and share } \\
\text { their story on these } \\
\text { social media sites. }\end{array}$ & $\begin{array}{l}\text { Must get in touch with } \\
\text { government bodies to plan } \\
\text { out how the waste can be } \\
\text { processed and make users } \\
\text { aware of it }\end{array}$ \\
\hline Pom Pom & New Delhi, India & $\begin{array}{l}\text { The start-up converts } \\
\text { all the accumulated } \\
\text { trash into their raw } \\
\text { form which can be } \\
\text { then used to make new } \\
\text { products. By a single } \\
\text { tap on the app, } \\
\text { doorstep service is } \\
\text { provided and the } \\
\text { respective person } \\
\text { collects all the trash } \\
\text { and pays the right } \\
\text { amount to the user. }\end{array}$ & $\begin{array}{l}\text { On the website of the start- } \\
\text { up, they can do a statistical } \\
\text { study as to how much } \\
\text { recyclable waste is } \\
\text { generated in each } \\
\text { household per week/per } \\
\text { month/per year and how } \\
\text { much the user can earn in } \\
\text { return. }\end{array}$ \\
\hline Ecolekt & Bangalore & $\begin{array}{l}\text { Features include click } \\
\text { and sharing the e-waste } \\
\text { and then schedule a } \\
\text { free pick up. In return } \\
\text { the user gets reward } \\
\text { points which can be } \\
\text { redeemed as gift } \\
\text { vouchers from various } \\
\text { online/offline stores of } \\
\text { their choice. }\end{array}$ & $\begin{array}{l}\text { The app must not be } \\
\text { confined to Bangalore. } \\
\text { They must expand and } \\
\text { cover more localities under } \\
\text { them. }\end{array}$ \\
\hline Sllixo & Bangalore & $\begin{array}{l}\text { Allows the user to } \\
\text { create an account on } \\
\text { the app and then go } \\
\text { either for buying or } \\
\text { selling of trash by } \\
\text { posting an ad. While } \\
\text { posting an ad, the user } \\
\text { has to mention the } \\
\text { quantity in terms of kg, } \\
\text { give a brief description } \\
\text { about the trash and } \\
\text { enter the price at which }\end{array}$ & $\begin{array}{l}\text { The application should } \\
\text { mention the names of the } \\
\text { buyers locality-wise. This } \\
\text { would help the people of } \\
\text { Bangalore to dispose off } \\
\text { their waste in much more } \\
\text { easy way. }\end{array}$ \\
\hline
\end{tabular}




\begin{tabular}{|c|c|c|c|}
\hline & & he/she wants to sell. & \\
\hline Encashea & Bangalore & $\begin{array}{l}\text { The user can select the } \\
\text { location for a suitable } \\
\text { pickup. The user is } \\
\text { given a referral code } \\
\text { by which he/she can } \\
\text { get } 5 \% \text { extra amount } \\
\text { on their next service, } \\
\text { when his/her friend } \\
\text { schedules a pickup } \\
\text { using the referral code. }\end{array}$ & $\begin{array}{l}\text { The application can add on } \\
\text { GPS features to it, so that it } \\
\text { accounts for more } \\
\text { convenience to its users. } \\
\text { The mobile application } \\
\text { should move to Tier-I } \\
\text { \&Tier-II cities for keeping } \\
\text { the environments clean, } \\
\text { instead of focusing only in } \\
\text { Bengaluru city. }\end{array}$ \\
\hline iScrap App & US and Canada & $\begin{array}{l}\text { Users in US \& Canada } \\
\text { can get information } \\
\text { about scrap metal } \\
\text { prices, directions, } \\
\text { business contact } \\
\text { information and much } \\
\text { more. The iScrap app } \\
\text { provides information } \\
\text { to scrappers, peddlers, } \\
\text { homeowners and } \\
\text { contractors like } \\
\text { plumbers and } \\
\text { electricians regarding } \\
\text { how to recycle their } \\
\text { scrap metals. }\end{array}$ & $\begin{array}{c}\text { They can add a favourite } \\
\text { option on all the scrap } \\
\text { yards, so that if a user } \\
\text { wants to visit the same } \\
\text { scrap yard which he/she } \\
\text { had visited earlier, can visit } \\
\text { easily. }\end{array}$ \\
\hline $\begin{array}{l}\text { Recyce for } \\
\text { Greater } \\
\text { Manchester }\end{array}$ & Manchester, UK & $\begin{array}{l}\text { With the help of GPS } \\
\text { technology, one can } \\
\text { find nearest Household } \\
\text { Waste Recycling } \\
\text { Centre, Furniture re- } \\
\text { use scheme, Charity } \\
\text { Shop and Electrical } \\
\text { Appliance Scheme. } \\
\text { Provides tips on how } \\
\text { to reduce food waste, } \\
\text { how to use real nappies } \\
\text { and tips on } \\
\text { composting, re-use } \\
\text { household items. }\end{array}$ & $\begin{array}{l}\text { The implementation of the } \\
\text { mobile application has to } \\
\text { be looked into as well as } \\
\text { the features defined by the } \\
\text { application must be } \\
\text { provided in a crystal clear } \\
\text { way, so as to reduce the } \\
\text { churning of customers. }\end{array}$ \\
\hline Smart Bin Mobile & USA & $\begin{array}{l}\text { IoT fill level sensors } \\
\text { are installed in bins } \\
\text { which indicate the user } \\
\text { on the app as to the } \\
\text { level of bin filled. The } \\
\text { other features of these } \\
\text { sensors are that it } \\
\text { measures all types of } \\
\text { materials and liquids } \\
\text { provided with GPS }\end{array}$ & $\begin{array}{l}\text { Knowledge of IoT sensors } \\
\text { and smart bins has to be } \\
\text { communicated to people on } \\
\text { a larger scale so as to get } \\
\text { more users on to the } \\
\text { application. Later the } \\
\text { mobile application can } \\
\text { expand its coverage after } \\
\text { capturing the market in } \\
\text { USA. }\end{array}$ \\
\hline
\end{tabular}




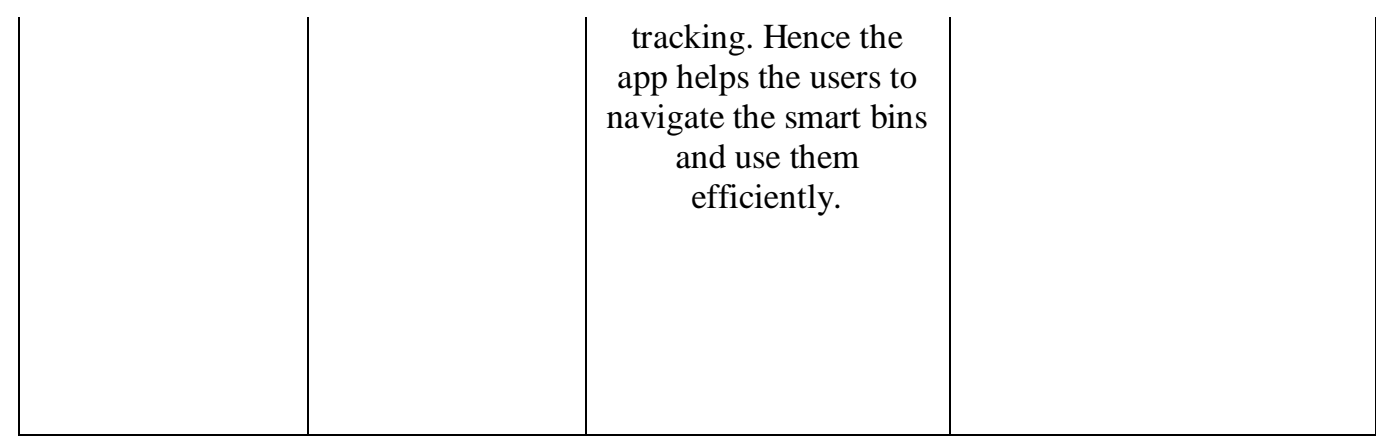

\section{Smart Retail}

Today, mobile is a very important touch point for retailers to retain customers. Smartphones enable consumers to access internet anytime and anywhere and play a crucial role when consumers shop both online and offline. Customers want to engage with retailers while buying and retailers must deliver experiences that match those expectations. Consumers demand convenient and personalized experiences and retailers struggle to satisfy these demands through their existing apps and mobile strategies.[8] A survey was conducted to know how often and in what contexts the customers use mobile apps and to find out how consumers use smart phones for retail activities. The results showed that customers use the smartphone to locate a store or check the store hours, to check order status, to read product reviews, to find a discount coupon, to compare prices with other stores, to learn about in-store promotion or event and many more. Consumers use retail apps for three main reasons: Convenience, Speed and Personalized Experience.[8] Retailers are very well aware of the challenges they face in getting consumers to download and use their apps. They must design apps that are differentiated, and provide a valuable customer experience thus giving reasons for consumers to come back to the app again.

\subsection{Qualitative Analysis of Mobile Applications in Smart Retail}

\begin{tabular}{|c|c|c|c|}
\hline Name of the app & REGION & Functioning of the app & Comments/ Recommendations \\
\hline India & $\begin{array}{c}\text { ePaisa app allows merchants } \\
\text { and retailers to accept } \\
\text { payments on the go, easily } \\
\text { integrate Sales and } \\
\text { Marketing tools. Through } \\
\text { this app it is possible to send } \\
\text { e-receipts, bills and invoices } \\
\text { via SMS or e-mail. Store } \\
\text { managers can track } \\
\text { inventory in real time and } \\
\text { access real time sales data } \\
\text { via cloud. This app can also } \\
\text { connect to a printer and } \\
\text { barcode scanner. }\end{array}$ & $\begin{array}{c}\text { This app is very useful for the } \\
\text { retail stores like BigBazar, } \\
\text { DMart, More Retail, etc where } \\
\text { the shoppers have to wait for a } \\
\text { long time for bill processing. } \\
\text { This app can help reduce the } \\
\text { crowd and mismanagement in } \\
\text { large stores and also help retailers } \\
\text { to smooth their processes. }\end{array}$ \\
\hline
\end{tabular}




\begin{tabular}{|c|c|c|c|}
\hline $\begin{array}{l}\text { MoWa- Mobile } \\
\text { Payments }\end{array}$ & India & \begin{tabular}{|} 
It helps pay money and \\
receive money from people \\
on your mobile. Through \\
this app you can make \\
payments to friends, family, \\
merchants with just their \\
phone number. It supports \\
all banks in India. Through \\
this app it's not required to \\
load money into an \\
additional account. You just \\
need to link your credit / \\
debit card \& pay directly \\
from it. Its main advantage \\
is that you no longer have to \\
share any bank account \\
details to anyone in order to \\
receive money.
\end{tabular} & $\begin{array}{l}\text { With payment banks coming up, } \\
\text { these kind of mobile apps also } \\
\text { have a good future. Especially in } \\
\text { small towns and villages where } \\
\text { we don't have many bank } \\
\text { branches, Mowa can help people } \\
\text { to access banking facilities by } \\
\text { linking their bank accounts with } \\
\text { this app. As we all know that } \\
\text { smart payments are one of the } \\
\text { features in smart city, so this app } \\
\text { is definitely going to play an } \\
\text { important part in it. }\end{array}$ \\
\hline TabShop-Point of Sale & US & \begin{tabular}{|} 
With this app, the mobile \\
becomes an easy to use \\
retail POS cashier that offers \\
support for Bitcoin credit \\
card payments. The cashier \\
system allows retailers to \\
print invoices in local \\
currency. It supports the \\
scan of QR code marked \\
products by using the \\
integrated cam of your \\
tablet. \\
\end{tabular} & $\begin{array}{l}\text { If all retail stores and restaurants } \\
\text { are equipped with this app, it can } \\
\text { benefit them by managing their } \\
\text { stocks and payments. It will } \\
\text { digitize their operations and thus } \\
\text { reduce mismanagement. So in a } \\
\text { smart city this app can play the } \\
\text { role of making the stores smart. It } \\
\text { will reduce dependence on } \\
\text { physical money and also benefit } \\
\text { customers. }\end{array}$ \\
\hline $\begin{array}{l}\text { Restaurant POS + } \\
\text { Ordering }\end{array}$ & Singapore & $\begin{array}{c}\text { This android app allows } \\
\text { customers to make quick } \\
\text { ordering by looking at food } \\
\text { pictures and even the waiter, } \\
\text { server or cashier can click } \\
\text { on the picture to confirm the } \\
\text { order. Orders can be taken } \\
\text { even when customers are } \\
\text { outside the outlet. Also the } \\
\text { payments can be collected } \\
\text { via the app. }\end{array}$ & $\begin{array}{l}\text { The basic aim of reducing the } \\
\text { dependence on printed money } \\
\text { and also simplifying the } \\
\text { operations of SMEs can be } \\
\text { fulfilled with such apps. Fast } \\
\text { ordering of food and fast delivery } \\
\text { are expectations of both the } \\
\text { customer as well as provider, so } \\
\text { these smart solutions will be } \\
\text { definitely welcomed by them and } \\
\text { can contribute in the smart city } \\
\text { concept. }\end{array}$ \\
\hline $\begin{array}{l}\text { Bigbasket - online } \\
\text { grocery }\end{array}$ & India & \begin{tabular}{|c|} 
It offers fresh fruits and \\
vegetables, groceries and \\
staples, spices, packaged \\
products, meat, beverages, \\
personal care products and \\
many more in the online \\
market. The app guarantees \\
on time delivery and quality \\
of the products.
\end{tabular} & $\begin{array}{l}\text { Online grocery delivery might } \\
\text { not seem a necessity but it is } \\
\text { definitely a parameter of making } \\
\text { a city smart. Such services must } \\
\text { be available in smart cities since } \\
\text { they ease the life of people and } \\
\text { also provides goods at lower } \\
\text { prices than the market }\end{array}$ \\
\hline
\end{tabular}




\begin{tabular}{|c|c|c|c|}
\hline $\begin{array}{c}\text { Netmeds- India Ki } \\
\text { Pharmacy }\end{array}$ & India & $\begin{array}{c}\text { Netmeds offers a range of } \\
\text { prescription and non- } \\
\text { prescription items, including } \\
\text { vitamins, diet supplements, } \\
\text { herbal products, pain } \\
\text { relievers. The nearest } \\
\text { pharmacy linked with } \\
\text { netmeds will promptly } \\
\text { deliver the medicines. It is } \\
\text { also possible to track the } \\
\text { order status in real time and } \\
\text { also view the prescription } \\
\text { history }\end{array}$ & $\begin{array}{l}\text { Online medicine shopping is a } \\
\text { new trend in India and is } \\
\text { currently restricted to the big } \\
\text { cities. But this initiative is } \\
\text { certainly worth appreciating since } \\
\text { many people face problem in } \\
\text { locating a pharmacy when there } \\
\text { is an urgent need. These apps } \\
\text { must be given a boost so that all } \\
\text { individuals can avail the facilities } \\
\text { of living in a smart city }\end{array}$ \\
\hline Amazon & $\begin{array}{l}\text { U.S. and } \\
\text { India }\end{array}$ & $\begin{array}{c}\text { Amazon app provides online } \\
\text { shopping of Electronics, } \\
\text { Books, Kitchenware, } \\
\text { Appliances, Healthcare, } \\
\text { Apparel, Sports, Shoes, } \\
\text { Jewellery, Furniture and } \\
\text { more }\end{array}$ & $\begin{array}{l}\text { Online shopping is the very basic } \\
\text { activity that people are engaging } \\
\text { in. Such apps are really needed in } \\
\text { today's world since people love } \\
\text { to shop from their homes. So a } \\
\text { smart city must be equipped with } \\
\text { such services and also the } \\
\text { villages around such cities should } \\
\text { be brought under the network of } \\
\text { online shopping }\end{array}$ \\
\hline
\end{tabular}

\section{Conclusion}

Success of such smart initiatives for urban mobility, smart waste management and smart retail etc in pursuit of creating harmonious and smart community living depends upon active involvement of all stakeholders. It is not just the Government or organisations with business interests who can nurture and grow these developmental solutions. A lot of involvement is required from common public resulting in co-creation of sustainable smart solutions. Awareness needs to be built among the citizens about the applications that they can leverage to simplify their day to day activities. It is only when citizens participate actively that city can be truly called smart.

In the Indian perspective, key success factors for implementation smart city solutions, will largely depend upon the level of citizen participation and project management capabilities at ULB/district levels by adapting to measurable KPIs. Recent announcements about Indian Smart City Plans (SCPs) have called for active involvement of Public private participations, especially the managed services providers (MSPs). A conducive and dynamic model for implementing and monitoring the "maturity level" of such initiatives is thus imperative.

\section{References}

[1] Smart Cities cornerstone series-URBAN MOBILITY IN THE SMART CITY AGE(PDF) by Schneider Electric and ARUP.

[2] Rajnish Tiwari (2012), Smart Mobility for India: Needs, Opportunities \& Challenges, GermanyContact India (Issue 02/2012, August), p. 16-17

[3] John Hagel, John Seely Brown, Tamara Samoylova, Kasey M. Lobaugh, Neha Goel (2015), The retail transformation - Cultivating choice, experience, and trust, Deloitte University Press

[4] Randall J. Miller (2015), Urban mobility redefined - Sharing is the new buying, Global Automotive \& Transportation Sector Leader, EY

[5] Arne Aslin, "Retail markups and the power of Amazon," MarketWatch, October 15, 2012, http://blogs.marketwatch.com/greatcolumnist/2012/10/15/retail-markups-and-thepower-of-amazon/, accessed March 11, 2015

[6] Ashlee Vance, "TechShop: Paradise for tinkerers," BusinessWeek, May 23, 2012, http://www.businessweek.com/ articles/2012-05-23/techshop-paradise-fortinkerers, accessed September 3,2014 
International Journal of $u-$ and e- Service, Science and Technology

Vol.10, No.4 (2017)

[7] A Forrester Consulting Thought Leadership Paper (2015), The State Of Mobile Apps For Retailers, Forrester Research

[8] Sustainable Urban Mobility (2016),UMii, the first Urban Mobility Innovation Index, https://eusmartcities.eu/content/dubai-presents-umii-first-urban-mobility-innovation-index

[9] The International Association of Public Transport (UITP), http://www.uitp.org/ 